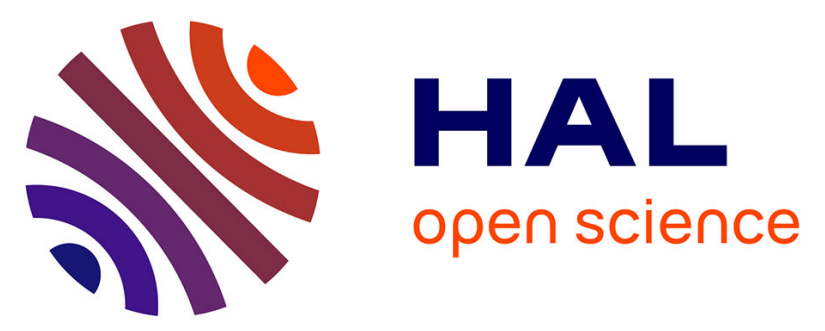

\title{
Can pluralistic approaches based upon unknown languages enhance learner engagement and lead to active social inclusion?
}

Rebecca Dahm

\section{- To cite this version:}

Rebecca Dahm. Can pluralistic approaches based upon unknown languages enhance learner engagement and lead to active social inclusion?. International Review of Education, 2017, 63 (4), pp.521-543. 10.1007/s11159-017-9636-3 . hal-01563586

\section{HAL Id: hal-01563586 \\ https://hal-univ-tlse2.archives-ouvertes.fr/hal-01563586}

Submitted on 17 Jul 2017

HAL is a multi-disciplinary open access archive for the deposit and dissemination of scientific research documents, whether they are published or not. The documents may come from teaching and research institutions in France or abroad, or from public or private research centers.
L'archive ouverte pluridisciplinaire HAL, est destinée au dépôt et à la diffusion de documents scientifiques de niveau recherche, publiés ou non, émanant des établissements d'enseignement et de recherche français ou étrangers, des laboratoires publics ou privés. 


\title{
Can pluralistic approaches based upon unknown languages enhance learner
}

\author{
engagement and lead to active social inclusion?
}

\author{
Rebecca Dahm ${ }^{1}$
}

\begin{abstract}
One way to foster active social inclusion is to enable students to develop a positive attitude to "foreignness". Creating a situation where mainstream students are less wary of foreign languages and cultures, and where newcomers feel their linguistic background is being valued, provides favourable conditions for the inclusion of these newcomers in the classroom and in society. However, language classrooms in French schools rarely take any previously acquired linguistic knowledge into account, thus unconsciously contributing to the rift between multilingual learners (e.g. 1st- and 2nd-generation immigrant children, refugees, children of parents with different mother tongues) and French learners. Native French learners' first experience of learning another language is usually when English is added as a subject to their curriculum in primary school. In some schools in France, English lessons now include the simulation of multilingual situations, designed in particular for the French "quasi monolingual" students to lose their fear of unknown languages and "foreignness" in general. But the overall aim is to help both groups of learners become aware of the positive impact of multilingualism on cognitive abilities. However, to achieve longterm effects, this awareness-raising needs to be accompanied by maximum engagement on the part of the students. This article explores an instructional strategy termed Pluralistic Approaches based upon Unknown Languages (PAUL), which was designed to develop learning strategies of quasi monolingual students in particular and to increase learner engagement more generally. The results of a small-scale PAUL study discussed by the author seem to confirm an increase in learner engagement leading to an enhancement of learning outcomes. Moreover, PAUL seems indeed suitable for helping to prepare the ground for social inclusion.
\end{abstract}

Keywords social inclusion; language learning; Pluralistic Approaches based upon Unknown Languages (PAUL); learning strategies; action research

Résumé Migrants et langue d'instruction: la déficience des politiques européennes stimule-t-elle l'innovation dans l'inclusion sociale ? L'apprentissage linguistique est depuis longtemps considéré comme un outil décisif pour atteindre les cibles de l'Union européenne (UE) en termes d'inclusion sociale. Cependant, les instruments stratégiques classiques tels que le plan d'action sur l'apprentissage des langues et la diversité linguistique ou la Charte européenne des langues régionales ou minoritaires ont été minés ces dernières années par les répercussions de la crise financière mondiale. Celle-ci a contribué à la décimation généralisée des budgets sociaux dans un grand nombre d'États membres de l'UE. Ce phénomène s'est accompagné d'une influence croissante du discours «néolibéral» dans les politiques et pratiques des services sociaux et d'assistance. En conséquence, les gouvernements centraux, régionaux et locaux ont délégué la responsabilité de la prestation des services à des entreprises commerciales, à la société civile et finalement aux citoyens. Parallèlement, les lacunes dans les prestations de service résultant de cette «crise financière » ont ouvert de nouvelles opportunités aux innovateurs sociaux. De nouvelles formes d'organisations se développent aujourd'hui et appliquent de nouvelles approches qui exploitent l'apprentissage des langues pour dispenser des services innovants. Ceux-ci visent entre autres à favoriser 
l'intégration des immigrants dans la société. À partir de l'analyse d'études de cas, l'auteur de l'article explore l'apparition de ces nouvelles approches, les types d'innovation actuellement concrétisés et la contribution de ces innovations sociales aux objectifs plus larges de l'UE relatifs à l'inclusion sociale.

${ }^{1}$ Rebecca Dahm $(\bowtie)$

ESPE Midi-Pyrénées/University of Toulouse-Jean Jaurès, Toulouse, France

e-mail: rebecca.dahm@univ-tlse2.fr

\section{Introduction}

Formal schooling in Europe has often been criticised for its monolingual habitus, even though recent changes in paradigm have been observed. Brigitta Busch contends that:

languages and varieties are no longer seen as clear-cut bordered units, but rather conceived as a bundle of communicative means, shaped by specific practices and ideologies, which speakers draw on in situated interactions (Busch 2011, p. 544).

Busch is referring to the trend launched by, among others, the Council of Europe and its Common European framework of reference for languages (CoE 2001), which aims to develop not only linguistic competence but also plurilingual and pluricultural competence among European citizens. Therefore, language teaching and learning is considered to be an "interaction process in which learners draw on all available linguistic resources" (Cathomas and Carigiet 2006, cited by Busch 2011, p. 544). Teachers are encouraged to valorise the different language repertoires of all learners in order to help them develop their multilingual ${ }^{1}$ competence which is considered to present positive cognitive aspects.

Indeed, research over the past thirty years has confirmed the advantages related to bi/multilingualism. Ellen Bialystok (1987) was able to demonstrate cognitive advantages which can be ascribed to bilingualism such as the increased ability of bilingual children to solve problems. Bialystok (ibid.) describes metalinguistic skills as strategies which are applied, either consciously or automatically, to a linguistic message and allow one to think about language and to control language processing within a communicative culture.

\footnotetext{
${ }^{1}$ The Council of Europe favours the use of the term "plurilingual", which refers to an individual's language repertoire, whereas "multilingual" is used to describe the range or the co-existence of different languages in a given society. However, the institutions of the European Union as well as many researchers, for more pragmatic reasons tend to use the term "multilingual" to cover both aspects, In this article, I have opted for the latter usage.
} 
Four years later, Jim Cummins stressed the "interdependence of first- and secondlanguage proficiency in bilingual children" (Cummins 1991) in his theory of Common Underlying Proficiency (CUP). He found that the use of two or more languages develops metalinguistic skills which can be regarded as a comprehensive monitoring system related to all languages known by one multilingual speaker. Further research (Bono 2008; Cenoz et al. 2001; Clyne 2003; Ringbom 2007) has underlined that these advantages are related to the heightened ability of multilinguals to reflect upon languages belonging to their multilingual repertoire. First, Laurent Gajo (2001), and then Philip Herdina and Ulrike Jessner (2002) determined the nature of this strategic advantage as being metalinguistic.

Despite the wide range of literature on the subject, bi/multilingual learners enrolled in French schools, especially those who have minority languages in their language repertoire, are rarely appreciated for their additional skills. Their non-French language(s) is/are not mentioned, and connections between languages are rarely made. Neither students nor teachers seem to be aware of existing research on the topic, and in cases where the teachers do know there might be a strategic advantage to multilingualism, they do not know how to help their students either develop this ability (Dahm 2013) nor do they resort to using it in a positive way. That is why, instead of running a campaign to inform students or teachers about the advantages of multilingualism, I considered it more promising to raise their multilingual awareness, building upon their own experience. Prompting students to develop a curiosity for languages seemed likely to help them open up to the unknown, and therefore to others; and valorising the linguistic capital of multilingual learners (MLL) from an immigrant background was thought to have the potential of contributing to their personal development. Both elements are crucial for social inclusion.

I therefore set up a small-scale study ${ }^{2}$ including action research, during which nine volunteer teachers took part in the development of didactic tools and reflected upon the impact on their students. Five of the teachers taught English as a foreign language in $5^{\circ}$ (seventh year of schooling) and the other four taught in $3^{\circ}$ (ninth year of schooling) ${ }^{3} \mathrm{My}$ analysis, however, was only based on the results of the sessions held with the Year 7 students ( $n=136)$ aged 12-13 in the Limousin and Aquitaine regions (France). The small-scale study discussed in this article was not about teaching a language, but about helping students become aware of their metalinguistic skills. For the purposes of the study and within the context of

\footnotetext{
${ }^{2}$ The design of the small-scale study is explained in more detail in the methodology section of this article.

${ }^{3}$ In France, children start primary school (which lasts five years; from CP to CM2) at age 6. They proceed to lower secondary school (four years, from $6^{\circ}$ to $3^{\circ}$ ) at age 11 , and to upper secondary school (three years from 2nde to Terminale) at age 15 , finishing at age 18 .
} 
their English lessons, the students were confronted with three unknown languages: Dutch, Italian and Finnish once a month, for the duration of one school year. None of their five teachers spoke the languages the sessions were about, so they were in the same position as their students. The instructional strategy, labelled "Pluralistic Approaches based upon Unknown Languages" (PAUL) ${ }^{4}$ was designed to make the students first try and understand a text in an unknown language (metasemantic tasks), then try and make up sentences in this language (metasyntactic tasks) and finally find ways to pronounce the language (metaphonological tasks).

Multilingual learners who are confronted on a daily basis with additional languages (not necessarily taught at school) unconsciously develop certain learning strategies (i.e. comparison, inferencing, deduction) when decoding and trying to use a new language. In order to explore whether the "quasi monolingual" population, ${ }^{5}$ whose daily experience did not include authentic multilingual situations, would be able develop such cognitive advantages, I grouped multilingual students separately from quasi monolinguals. Moreover, to prevent the involvement of any kind of preconceptions in the problem-solving tasks, none of the students were told which languages they would be working on. The expectation was that the combination of these two conditions (separation and non-disclosure) would evoke an attitude of curiosity and help to develop the students' self-esteem (Dahm 2014). Out of this set-up, the following research questions then emerged:

(1) Do Pluralistic Approaches based upon Unknown Languages (PAUL) enhance learner engagement?

(2) If so, can learner engagement improve learning outcomes, thus fostering a positive attitude towards "foreignness" and eventually facilitate social inclusion?

To examine these research questions, the research team got students engaged in nine PAUL sessions, three for each language. Michel Candelier (2008) defines pluralistic approaches as didactic approaches which use teaching/learning activities involving several varieties of languages or cultures. However, PAUL sessions take this one step further as they are conducted in a systematic and regular way, thus enabling both near and far transfer of

\footnotetext{
${ }^{4}$ The study was carried out in French. The French term for the instructional design was Approches Plurielles fondées sur des Langues Inconnues (APLI).

${ }^{5}$ For reasons of clarity, I have chosen to label those students "quasi monolingual" who had declared (in a survey preceding the actual study) that they had no contacts in their direct environment with languages other than their first language (L1), French, and the second language (L2), English, they were being being taught as a subject at school. This shortcut, while it only relies upon statements, enables me to distinguish between multilinguals and their non-multilingual peers which is useful for focusing my analysis on the latter. However, participants included both multilingual and non-multilingual students.
} 
learning $^{6}$ as well as providing comparable results (one session per month, over an entire school year). As noted before, students were confronted with a succession of metasemantic, metasyntactic and metaphonological tasks for each unknown language. To solve the problems they were presented with, they needed to build upon their prior knowledge of different linguistic systems, which for the quasi monolinguals would be their first language (L1), French, and their school subject and second language (L2) English.

Taking into account the entire instructional approach, this article endeavours to assess the level of cognitive engagement PAUL sessions can elicit, analyse the effects of engagement on learning outcomes (for the quasi monolinguals in particular) and explore the potential of these to prepare the ground for active inclusion of learners from a migrant background.

\section{Theoretical background}

Before exploring the way PAUL sessions enable students to actively engage in their learning, it is essential to clearly define social inclusion and how learner engagement is considered. After that, I will examine the importance of group work and its possible effects on social inclusion and then proceed to presenting the methodology of the small-scale study under discussion in this paper.

What is inclusion, and what is social inclusion through language learning?

Inclusion, in a general sense, is being part of a group. In social inclusion, this group is a society or a community. Language learning is often seen as a means to bridge the gap between communities. Indeed, the European Union policy agenda emphasises the value of mother-tongue and bilingual education, which can lead to social inclusion through language learning. As Barry van Driel, Merike Darmody and Jenniver Kerzil state:

Research findings also show immigrant languages tend to be least recognised, protected and/or promoted compared to other types of languages (e.g. national, foreign, regional languages) despite positive recognition in EU policy agenda (Extra and Yagmur 2012). This may be detrimental to the academic success of minority language students and negatively impact their self-esteem and sense of

\footnotetext{
${ }^{6}$ Near transfer of learning refers to the ability of using skills learned during one particular situation for tackling another very similar situation. Far transfer of learning refers to the ability to apply such skills in an entirely different situation.
} 
belonging. The evidence shows that recognition of the value and importance of migrants' linguistic heritage is critically important (Van Driel et al. 2016, p. 46).

The European Commission recognised this and in 2013 launched a three-year project aiming to establish a pan-European non-profit network called "INCLUDE" to "pursue the goal of a more inclusive society through language learning" (INCLUDE 2014). INCLUDE (not an acronym) is part of the European Commission's lifelong learning programme, and the network comprises policy makers, institutional representatives, local authority administrators, managers, teachers and educators, and volunteers working in social advancement associations. ${ }^{7}$ Having analysed several major policy reviews on Social Inclusion, members of the INCLUDE network underline that opportunities for informal and non-formal learning designed for both migrant and non-migrant community members of all ages can broaden the solidarity of society and form a link to migrant or ethnic minority families. In their Roadmap for integration of language learning in inclusion policies in Europe, INCLUDE network members Nicola Orlando and Joe Cullen state that

Languages/language skills already play or could play a relevant role in promoting (active) social inclusion to [...] fight any form of discrimination by promoting and protecting linguistic diversity as well as regional and minority languages, by reinforcing the learning at school of the host and heritage languages for children from a migrant background [...] (Orlando and Cullen 2016, p. 10).

Research into social inclusion makes us become aware of the importance of identity. One of the ways for the European Union to enhance social inclusion is through lifelong learning. However, this approach has often been seen as "a philosophy of identity where all humans are supposed to share common goals and motives" (Nordin 2008, p. 5). Richard Edwards, Paul Armstrong and Nod Miller take this further, declaring:

What we wish to argue is that inclusion is primarily positioned within a philosophy of identity that denies difference. Within this stance inclusion and exclusion are described as binary opposites, in which the latter can be transcended to achieve the former (Edwards et al. 2001, p. 423).

\footnotetext{
${ }^{7}$ The six founding organisations are: (1) Istituto per la Ricerca Sociale (IRS) - Italy; (2) Iniciativas Innovadoras S.A.L.(IN) - Spain; (3) Agenzia per l'Orientamento e la Formazione, Istruzione e Lavoro (APOF-IL) - Italy; (4) Université de Bordeaux-LACES - France; (5) Vytautas Magnus University - Lithuania; and (6) Arcola Research LLP - United Kingdom. For more information about the network, see http://www.includenetwork.eu/ [accessed 9 March 2017].
} 
Andreas Nordin, who carried out an extensive literature review using the database of the Education Resources Information Center (ERIC), investigated the different approaches of inclusion/exclusion in educational research. He underlines that

the stigmatisation of the others as abnormal becomes a powerful technique affecting the process of subjection. By adopting a dichotomist vocabulary using words like normal/abnormal and natural/unnatural, individual behaviour becomes strongly affected; not necessarily in any obvious way but in the way people talk, choose and act as active subjects (Nordin 2008, p. 10).

It therefore seems reasonable to ponder how it might be possible to value difference in a positive way, overcoming the dichotomist vocabulary and enabling people to feel included rather than integrated "into the normative group who have already accepted the lifelonglearning narrative" (Lindblad 2005, p. 44). This is one of the goals of PAUL sessions, since students participating in these not only learn to collaboratively build upon one another's knowledge; they are also enabled to overcome preconceived ideas about unknown languages, or the unknown/"foreignness" in general. However, to do so, they need to really engage in their learning.

\section{How do students engage in learning?}

Researchers have defined engagement in many different ways, but generally speaking, engagement refers to "the extent of a student's active involvement in a learning activity", as stated by James Wellborn (1991). However, it is possible to consider engagement from different viewpoints, in terms of whether it is seen from a motivational, a behavioural or an emotional perspective. As Michelene Chi and Ruth Wylie put it,

When engagement is discussed in motivational terms, it tends to mean the precursor attitude or interest in getting involved with the learning materials. Behavioral engagement refers generally to the notion of participating and addresses large-grained measures, such as how often students attend class or do homework, whereas emotional engagement encompasses measures of positive and negative reactions to teachers, classmates, academics, and so on (Chi and Wylie 2014 , p. 219; italics in the original).

\footnotetext{
${ }^{8}$ It is important to note that there is a difference in these two terms. While inclusion respects and fosters nonmainstream characteristics with the aim of including individuals on their own terms, integration refers to the aim of adjustment to mainstream characteristics.
} 
Indeed, the distinction between behavioural and emotional engagement is also underlined by Johnmarshall Reeve (2012). However, he, describes four types of engagements: in addition to behavioural and emotional engagement, he also discerns cognitive engagement, which he defines as the "usage of sophisticated rather than superficial learning strategies", and agentic engagement, which refers to the extent to which the learner "tries to enrich the learning experience rather than just passively receive it as a given" (ibid., p. 150).

Even though PAUL sessions can be analysed according to the full spectrum of learner engagement, this article focuses on cognitive engagement, thus analysing the "overt behaviours that students can undertake and teachers can see" (Chi and Wylie 2014, p. 220). Chi and Wylie's established taxonomy describing four modes of engagement is known as the Interactive-Constructive-Active-Passive (ICAP) framework. An overview (Table 1) of the ICAP taxonomy (Chi and Wylie 2014) seems helpful to better understand these four modes of engagement, their underlying knowledge-change processes, the expected changes in knowledge as well as the expected cognitive and learning outcomes.

Table 1 Overview of the Interactive-Constructive-Active-Passive (ICAP) framework by Chi and Wylie (2014)

\begin{tabular}{|c|c|c|c|c|c|}
\hline $\begin{array}{c}\text { Modes of } \\
\text { engagement }\end{array}$ & Descriptors & $\begin{array}{c}\text { Knowledge- } \\
\text { change } \\
\text { processes }\end{array}$ & $\begin{array}{l}\text { Expected } \\
\text { changes in } \\
\text { knowledge }\end{array}$ & $\begin{array}{l}\text { Expected } \\
\text { cognitive } \\
\text { outcomes }\end{array}$ & $\begin{array}{l}\text { Learning } \\
\text { outcomes }\end{array}$ \\
\hline Passive & $\begin{array}{l}\text { receiving } \\
\text { information }\end{array}$ & $\begin{array}{l}\text { storing } \\
\text { information }\end{array}$ & $\begin{array}{l}\text { New } \\
\text { knowledge is } \\
\text { stored in an } \\
\text { encapsulated } \\
\text { way. }\end{array}$ & $\begin{array}{l}\text { being able to } \\
\text { recall } \\
\text { information } \\
\text { verbatim in an } \\
\text { identical } \\
\text { context (near } \\
\text { transfer of } \\
\text { learning) }\end{array}$ & $\begin{array}{c}\text { minimal } \\
\text { understanding }\end{array}$ \\
\hline Active & $\begin{array}{l}\text { manipulating } \\
\text { information }\end{array}$ & $\begin{array}{l}\text { integrating } \\
\text { information } \\
\text { with prior } \\
\text { knowledge }\end{array}$ & $\begin{array}{l}\text { Existing } \\
\text { schema is more } \\
\text { complete, } \\
\text { coherent, } \\
\text { salient, and } \\
\text { strengthened. }\end{array}$ & $\begin{array}{l}\text { being able to } \\
\text { apply } \\
\text { information to } \\
\text { similar but } \\
\text { non-identical } \\
\text { situations } \\
\text { (extended } \\
\text { transfer of } \\
\text { learning) }\end{array}$ & $\begin{array}{c}\text { shallow } \\
\text { understanding }\end{array}$ \\
\hline Constructive & $\begin{array}{l}\text { generating } \\
\text { new } \\
\text { knowledge }\end{array}$ & $\begin{array}{l}\text { inferring } \\
\text { new } \\
\text { knowledge }\end{array}$ & $\begin{array}{l}\text { New inferences } \\
\text { create new } \\
\text { knowledge } \\
\text { beyond what } \\
\text { was encoded. }\end{array}$ & $\begin{array}{l}\text { being able to } \\
\text { transfer } \\
\text { learned skill to } \\
\text { novel context } \\
\text { or distant }\end{array}$ & $\begin{array}{c}\text { deep } \\
\text { understanding }\end{array}$ \\
\hline
\end{tabular}




\begin{tabular}{|c|c|c|c|c|c|}
\hline & & & & $\begin{array}{l}\text { problem (far } \\
\text { transfer of } \\
\text { learning) }\end{array}$ & \\
\hline Interactive & $\begin{array}{l}\text { dialoguing } \\
\text { with peers }\end{array}$ & $\begin{array}{l}\text { co-inferring } \\
\text { new } \\
\text { knowledge }\end{array}$ & $\begin{array}{l}\text { New } \\
\text { knowledge and } \\
\text { perspectives } \\
\text { can emerge } \\
\text { from co- } \\
\text { creating } \\
\text { knowledge that } \\
\text { neither partner } \\
\text { knew. }\end{array}$ & $\begin{array}{l}\text { being able to } \\
\text { co-create: } \\
\text { invent new } \\
\text { products, } \\
\text { procedures, } \\
\text { etc. }\end{array}$ & $\begin{array}{c}\text { deepest } \\
\text { understanding }\end{array}$ \\
\hline
\end{tabular}

In a nutshell, Chi and Wylie's taxonomy suggests that engaging students in an interactive mode during which they co-infer knowledge, thus creating new knowledge none of the partners knew before, should lead to the deepest possible understanding.

\section{The importance of group work}

Group work fosters cohesion: when learners belong to a group in which they do not feel intimidated, they engage more in their learning and dare to take risks (e.g. getting the grammar wrong when they contribute to discussions within the group). Furthermore, allowing students to interact as part of a small group can, as John Dewey already mentioned in 1916 (Dewey 1966 [1916]), bring out certain capacities of an individual that are stimulated by the association with others. Working in groups provides an opportunity for students to increase the number of their interactions, to explore new ways without being under the teacher's assessing scrutiny, and to share knowledge and expertise.

Rod Ellis (2003) argues that group work results in cooperative learning through collaborative dialogue. For Merrill Swain, collaborative dialogue is a "dialogue in which stakeholders undertake problem solving and build up knowledge" (Swain 2000, p. 102). In our study, we were able to trace the cognitive operations carried out by the students by analysing both the results/learning outcomes of each group's work and the operations documented in transcripts of the interactions during the PAUL sessions.

Having established that group work is essential to the achievement of the proposed tasks, it was obvious to the research team that it would be vital to each session. This specificity of PAUL sessions led us to review the didactic situation. Starting out from the pedagogical triangle of Jean Houssaye (1988), which links the vertexes Teacher, Learner and Knowledge, we moved on to the pedagogical tetrahedron of Richard Faerber (2002), which 
links the Teacher, Learner and Knowledge to a fourth vertex, the Group. Though Faerber is referring to distance learning groups, and our sessions were not embedded in a virtual learning environment, this tetrahedron is of great interest, since it introduces the element of the group. Indeed, as part of our study, the group obtained a legitimate status whose existence was confirmed by the students' use of the collective pronoun "we" instead of "I" when they were working on the metalinguistic tasks.

I chose to adapt this tetrahedron using a number of processes defined by Houssaye (1988) and Faerber (2002) in order to reflect the specific nature of the teaching situation created by our PAUL strategy (see Figure 1). The adjustments I made to underline the importance of the "group" vertex were as follows:

PAUL sessions become the mediating knowledge agent. The various processes involved depend on PAUL which is then at the centre of the tetrahedron. The session is more of a tool or a medium than a goal in itself.

- The PAUL tetrahedron has six core processes, three of which are derived from Houssaye's pedagogical triangle (teaching, learning, training). The other three processes involve the "group" vertex (collaborating, solving, facilitating). The relationship established between the student and the group is a collaborative relationship: both observe the knowledge presented (through the unknown language) and work together to pool their resources. The problem-solving process is made possible by the exchange of ideas, the sharing of distributed knowledge (Pea 1998). There is a shift from the "training" process characterising the dual teacher-student relationship to the "facilitating" process, representing the dialogue which takes place between the group and the teacher: his/her role is similar to that of a "facilitator" who guides the group in its reflection rather than that of a teacher trying to train the individual. 


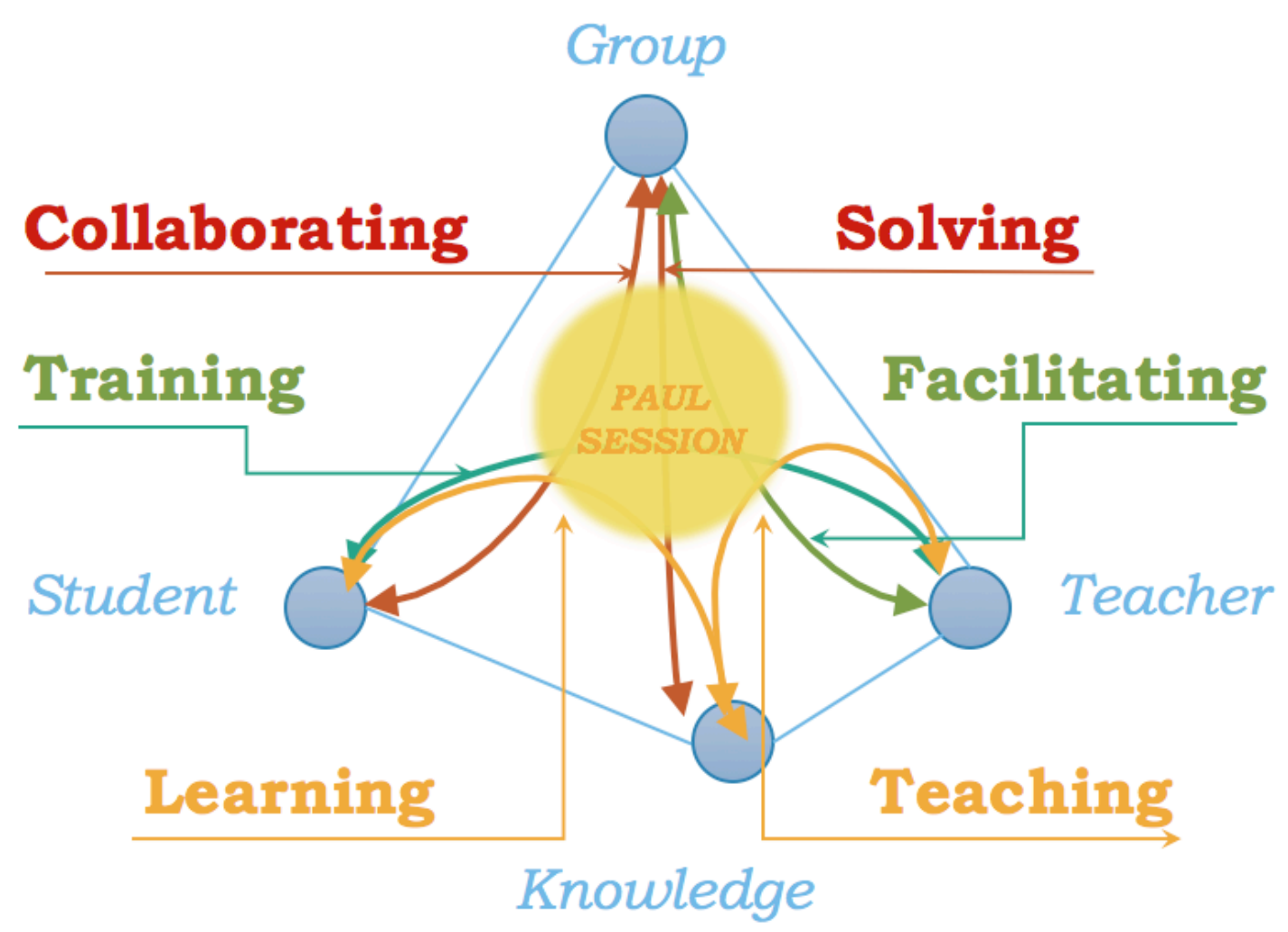

Figure 1 Pedagogic tetrahedron representing the didactic situation created in PAUL sessions

The PAUL tetrahedron (Figure 1) puts an emphasis on the group which is most probably one of the essential components of society. Indeed, as the Cambridge Advanced Learner's Dictionary puts it, society is "a large group of people who live together in an organized way, making decisions about how to do things and sharing the work that needs to be done" (McIntosh 2013). Thus, inclusion only seems possible if people work together, sharing ideas and values. Therefore, making students work in groups can be considered as one of the first steps to prepare the ground for social inclusion. Indeed, group work enables an improved behavioural and emotional engagement and increases the cognitive level of engagement. It is only through efficient engagement and social interaction that steps can be taken on the path towards social inclusion.

In the next two sections, I will present first the methodology and then the general results of our small-scale study regarding the impact of students' active engagement on learning outcomes. The concluding section will explore how these PAUL sessions might be used to improve active social inclusion.

\section{Methodology}


The small-scale study under discussion here is part of a larger study which was carried out in the regions of Limousin and Aquitaine (France). It involved five lower secondary school teachers and 136 Year 7 students aged 12 to 13 from five classes at four schools, throughout one full school year. All five teachers also taught same level of English classes, which then became the control group $(n=132)$ : they benefited from the same teaching of the subject of English, but did not experience the PAUL sessions. Pre-tests and post-tests evaluating the ability to solve access-to-meaning problems and explaining the implemented strategies were administered to both the sample group and the control group. As mentioned earlier, in order to be able to assess the specific impact of the PAUL sessions on their learning strategies, I decided not to mix multilingual students with quasi monolingual ones. Out of the total sample of 136 students, 88 students were monolingual in their family environment. It was this subsample I was particularly interested in.

In a survey preceding the actual study, I asked students to provide information regarding their language use in the family environment and at school. Thus I was able to single out and observe 88 students who were all native speakers of French and who had only been learning English as a foreign language for four years.

In order to enhance learner engagement and to be able to monitor the implemented learning strategies, I set up 22 groups of 4 students (or “tetrads"). Peer-to-peer explanations of a linguistic feature are said to be beneficial for second language (L2) development (Hulstijn and Hulstijn 1984). It was therefore likely that the verbalisation of their understanding of the text in the unknown language would help the students become aware of the learning strategy they resorted to. However, in order to be able to assess the depth of the learning outcome, it was necessary to explore the extent to which the learners' engagement during this dialoguing activity is constructive or truly interactive.

In order to be able to compare the specific impact of PAUL sessions on engagement and learning strategies, we submitted a semantic pre- and post-test to both the control group $(n=132)$ and to our participating sample group $(n=88)$ described above. This "participating sample group" was composed of the 22 tetrads, set up according to various parameters (gender ${ }^{9}$, learner of Latin, other L2, willingness to learn other languages, interest in reflexive practice, own perception of grammar skills, results of pre-test) extracted from both the semantic pre-test and the pre-survey so as to be heterogeneous, yet of comparable structure. Finally, a post-study survey was also set up to gather data about their use of strategies outside school.

\footnotetext{
${ }^{9}$ The sample group was composed of 45 girls and 43 boys, and each tetrad was mixed-gender.
} 
The small-scale engagement study discussed in this article is part of a larger study (Dahm, 2013) based on PAUL sessions, designed to confront students successively with three unknown languages, namely Dutch (NL; chosen because of its typological proximity to English); Italian (It; close to French) and Finnish (Finn), an agglutinative language, which presents no immediate similarity with any Indo-European language the students might know. All sessions followed the same model to provide a certain systematicity in their regular exercise and to allow comparison of the results. They took place on a monthly basis. For each language, the set-up of the larger study included three successive sessions (S1-S3) of linguistic problem-solving tasks: (1) understanding the text (metasemantic tasks); (2) creating new sentences (metasyntactic tasks); and finally (3) trying to pronounce the unknown language (metaphonological tasks). As the nine sessions were spread across a school year, there was a gap of a month between each of the sessions. With the languages being treated one after the other (session 1 for e.g. Italian was held 3 months after session 1 for Dutch), it would be difficult for the students to simply remember and apply the skills learned during the first session. Therefore, it seemed likely that any heightened ability to solve linguistic problems would be related to a transfer of metalinguistic strategies.

This article focuses on the results of the metasemantic (session 1) and metasyntactic (session 2) tasks. In the first part of session 1, students were asked to reflect upon those elements of the language at hand which they understood or recognised, underlining the relevant items and writing down their ideas. This learning task was implemented individually, completed on a personal sheet and lasted five minutes. In the second part of session 1 , students worked in their tetrad groups to share their findings and better understand the text. They were asked to fill in an answer sheet collaboratively to explain what they understood and how they managed to understand these elements. In the third part of session 1, the groups' findings were discussed in class. During session 2, students were asked to create new sentences in the language they had explored during the previous session. To do so, they needed to carry out a grammatical analysis to be able to create new sentences as correctly as possible. As the students were conducting a dialogue and co-inferring new meaning and new sentences, they were undertaking the highest level of cognitive engagement.

I believed that comparing the students' individual findings with the group results should make it possible to gauge the extent to which these two modes of engagement (active and interactive) led to different learning outcomes. I began with a quantitative analysis of both the individual and collective worksheets, and then complemented this with a qualitative analysis, to understand exactly how new knowledge is created. In order to analyse the results with 
NVivo (a nodal analysis tool), I recorded all group discussions and saved them on mp3 recorders, then transcribed them whenever relevant. These qualitative data then enabled me to explore in what way PAUL sessions can lead to enhanced learner engagement.

\section{Results and discussion}

Do PAUL sessions enhance learner engagement?

According to Chi and Wylie, the process inherent to the interactive mode of engagement enables students to "co-create new knowledge that neither partner knew" (Chi and Wylie 2014, p. 220), which leads to the deepest understanding. To maximise learner engagement, it seemed plausible that through dialoguing, the students would co-infer new meaning. However,

Co-inferring processes involve both partners taking turns mutually creating. This mutuality further benefits from opportunities and processes to incorporate feedback, to entertain new ideas, alternative perspectives, new directions, etc. (Chi and Wylie 2014, p. 214).

To be able to describe the overt activities, one cannot simply rely on the instructional design which is set up to have students engage interactively. It is necessary to carry out a qualitative analysis of the interactions going on to verify whether students manage to co-create new knowledge, either during metasemantic or metasyntactic PAUL sessions.

The analysis of the individual sheets ${ }^{10}$ revealed an affirmative answer rate of $31 \%$ for the session on Dutch, $38 \%$ for the session on Italian and $46 \%$ for the session on Finnish. However, these answer rates do not take into account the accuracy of the answers; they only reflect the number of elements the students declared having understood. They reached an active level of engagement, since they manipulated (to use Chi and Wylie's term; see Table 1) the new knowledge. They were expected to be able to apply (transfer) the same processes to similar but non-identical situations. I did indeed find an increase in their learning outcome, but it seems difficult to state that this was merely due to their active level of engagement, since each individual reflection was followed by group work. Therefore, a qualitative analysis of the recorded interactions would enable me to check whether students were duly engaged and whether/how the dialogue led to the desired learning goal.

\footnotetext{
${ }^{10}$ Students were asked to underline and indicate what they understood, and then to count the number of elements they had managed to understand.
} 
For the purposes of this article, I have chosen two excerpts from the transcriptions of the metasemantic session on Dutch ${ }^{11}$ to underline the part played by the group and to analyse the role of the teacher. In Excerpt 1, the relationship established between the teacher and the group is a "facilitating" relationship, representing the dialogue set up between these two vertexes of the tetrahedron during one of the metasemantic PAUL sessions. The female teacher (P1) is helping group members to compare their ideas, creating a strong identity within the group through the negotiation she is encouraging.

\begin{tabular}{|c|c|c|c|}
\hline $\begin{array}{c}\text { Speaking } \\
\text { turns }\end{array}$ & Speaker & French transcription & $\begin{array}{l}\text { English translation } \\
\text { (for the purposes of this article) }\end{array}$ \\
\hline 82 & Inès & $\begin{array}{l}\text { [s'adresse à l'enseignante] : } \\
\text { Alors là, c'est juste Caroline } \\
\text { qui a trouvé et qui a dit qu'elle } \\
\text { habite chez ses parents, c'est } \\
\text { ça? }\end{array}$ & $\begin{array}{l}\text { [addressing the teacher]: } \\
\text { Well here, it's just Caroline who } \\
\text { has found and who said that she } \\
\text { lives with her parents, right? }\end{array}$ \\
\hline 83 & Caroline & Oui... & Yes ... \\
\hline 84 & Inès & $\begin{array}{l}\text { Enfin, elle a trouvé ça à l'écrit } \\
\text { parce que elle voyait que ça ça } \\
\text { ressemble à des prénoms et elle } \\
\text { a trouvé que in Amsterdam, ça } \\
\text { ça ressemble à de l'anglais... }\end{array}$ & $\begin{array}{l}\text { After all, she found that in the } \\
\text { writing because she saw that it ... } \\
\text { it resembles first names and she } \\
\text { found that in Amsterdam, it ... } \\
\text { it's similar to English }\end{array}$ \\
\hline 85 & $\begin{array}{l}\text { P1 (female } \\
\text { teacher) }\end{array}$ & $\begin{array}{l}\text { Donc toi tu penses que Marijke } \\
\text { et Geert, ce sont des noms de } \\
\text { personnes...? }\end{array}$ & $\begin{array}{l}\text { So you think that Marijke and } \\
\text { Geert are names of people? }\end{array}$ \\
\hline 86 & Inès & $\begin{array}{l}\text { Moi je pensais que c'était une } \\
\text { rue... }\end{array}$ & Me, I thought it was a street ... \\
\hline 87 & P1 & $\begin{array}{l}\text { Ah, alors il faut vous mettre } \\
\text { d'accord. }\end{array}$ & $\begin{array}{l}\text { Well, you have got to agree } \\
\text { among yourselves. }\end{array}$ \\
\hline 88 & Damien & $\begin{array}{l}\text { En plus on ne peut même pas } \\
\text { les lire. }\end{array}$ & $\begin{array}{l}\text { What's more, it's almost } \\
\text { impossible to read them. }\end{array}$ \\
\hline 89 & P1 & $\begin{array}{l}\text { Alors pourquoi tu penserais que } \\
\text { ce seraient des parents là... Va } \\
\text { plus loin... C'est intéressant! }\end{array}$ & $\begin{array}{l}\text { Well, why do you think that those } \\
\text { are the parents there. Go a bit } \\
\text { further ... It's interesting! }\end{array}$ \\
\hline 90 & Inès & $\begin{array}{l}\text { Mais là ça ressemble parce que } \\
\text { là il y } a \ll O-U-D \text { » et là il y a } \\
\text { «E-R-S». }\end{array}$ & $\begin{array}{l}\text { Bt here it's similar because here it } \\
\text { says "O-U-D" and there it says } \\
\text { "E-R-S" }\end{array}$ \\
\hline 91 & P1 & Oui... & Yes. \\
\hline
\end{tabular}

Excerpt 1 Partial transcript of Dutch, session 1 (NLS1), group A4

Excerpt 1 reflects that this teacher plays a very limited role: her answers are reduced to the mirror technique and engage the students in a constructive exchange. She lets them compare their ideas so that they reach a consensus. She perfectly complies with the role of the teacher

\footnotetext{
${ }^{11}$ Please report to Appendix 1 for the original text in Dutch.
} 
as described by Ellis (2003, p. 271): this role can go from observation to intervention when a group has got stuck. However, the degree of intervention should be minimal, so as not to deconstruct the relationship within the group.

For a didactic mediation to be effective, the teacher must guide the student (or group, in our case) in the construction of their own knowledge of the language (Deyrich 2001, p. 143). It comes down to "guiding" reflection so that students can build their meta-linguistic representation system by themselves. However, often the guidance is too deliberate, as is apparent in Excerpt 2.

\begin{tabular}{|c|c|c|c|}
\hline $\begin{array}{l}\text { Speaking } \\
\text { turns }\end{array}$ & Speaker & French transcription & $\begin{array}{l}\text { English translation } \\
\text { (for the purposes of this article) }\end{array}$ \\
\hline 11 & $\begin{array}{l}\mathrm{P} 2 \\
\text { (female } \\
\text { teacher) }\end{array}$ & $\begin{array}{l}\text { Donc 'ma famille', c'est pas } \\
\text { exactement ça, mais c'est pas } \\
\text { grave... Qu'est-ce que ça veut } \\
\text { dire zijn naam. De qui on } \\
\text { parle dans la phrase? }\end{array}$ & $\begin{array}{l}\text { So, "my family", it's not exactly } \\
\text { that, but it doesn't matter ... What } \\
\text { does it mean, zijn naam? Who is } \\
\text { this sentence about? }\end{array}$ \\
\hline 12 & Fabien & De son frère & About his brother \\
\hline 13 & $\mathrm{P} 2$ & Ça veut dire quoi zijn naam? & Is that what zijn naam means? \\
\hline 14 & Fabien & Il s'appelle & He's called \\
\hline 15 & Pierre & Son nom est & His name is \\
\hline 16 & $\mathrm{P} 2$ & $\begin{array}{l}\text { Pierre, je t'ai pas interrogé, } \\
\text { là... Après on parle de qui? } \\
\text { Après, on parle de qui et } \\
\text { qu'est-ce qu'on dit: haar } \\
\text { naam? }\end{array}$ & $\begin{array}{l}\text { Pierre, I wasn't asking you, there } \\
\ldots \text { So who are we talking about? } \\
\text { Who are we talking about and } \\
\text { what should we say? haar nam? }\end{array}$ \\
\hline 17 & Fabien & Son nom... & Her name ... \\
\hline 18 & $\mathrm{P} 2$ & $\begin{array}{l}\text { Son nom. C'est quoi ces mots : } \\
\text { mon, son...Quand tu parles de } \\
\text { la voiture de tes parents, tu dis } \\
\text { quoi, c'est...? }\end{array}$ & $\begin{array}{l}\text { Her name. What are these words: } \\
\text { my, her ... When you talk about } \\
\text { your parents' car,* what do you } \\
\text { say, it's ...? } \\
{\left[{ }^{*} \text { in French, a car is feminine] }\right.}\end{array}$ \\
\hline 24 & $\mathrm{P} 2$ & $\begin{array}{l}\text { Quand tu parles de la salle de } \\
\text { classe, tu dis c'est notre salle } \\
\text { de classe. Alors, mon, ton, } \\
\text { son, notre, leur, c'est quoi ces } \\
\text { mots? C'est des pronoms } \\
\text { comment...? }\end{array}$ & $\begin{array}{l}\text { When you talk about the } \\
\text { classroom, you say it's our } \\
\text { classroom. So my, your, his/her, } \\
\text { our, their, what kind of words are } \\
\text { they? They are what kind of } \\
\text { pronouns ...? } \\
\text { [*son can mean either his or her] }\end{array}$ \\
\hline 25 & Fabien & personnels & personal \\
\hline 26 & $\mathrm{P} 2$ & Oh là, là... & Oh dear ... \\
\hline 27 & Fabien & Euh non, non! & Erm, no, no! \\
\hline 24 & $\mathrm{P} 2$ & $\begin{array}{l}\text { Quand tu parles de la salle de } \\
\text { classe, tu dis c'est notre salle } \\
\text { de classe. Alors, mon, ton, } \\
\text { son, notre, leur, c'est quoi ces } \\
\text { mots? C'est des pronoms }\end{array}$ & $\begin{array}{l}\text { When you talk about the } \\
\text { classroom, you say it's our } \\
\text { classroom. So my, your, his/her, } \\
\text { our, their, what kind of words are } \\
\text { they? They are what kind of }\end{array}$ \\
\hline
\end{tabular}




\begin{tabular}{|c|c|c|c|}
\hline & & comment...? & pronouns ...? \\
\hline 28 & $\mathrm{P} 2$ & $\begin{array}{l}\text { Qu'est-ce que vous exprimez } \\
\text { quand vous dites "mon } \\
\text { nom», c'est...? Un nom qui } \\
\text { est à...? }\end{array}$ & $\begin{array}{l}\text { What are you expressing when } \\
\text { you say "my name", it's ...? A } \\
\text { name which belongs to ...? }\end{array}$ \\
\hline 32 & Fabien & C'est le sien & Its his/hers \\
\hline 33 & $\mathrm{P} 2$ & $\begin{array}{l}\text { Oui, bin c'est ça, c'est bien, } \\
\text { donc c'est un rapport de...? } \\
\text { De po...? }\end{array}$ & $\begin{array}{l}\text { Yes, that's right, good, so, it's a } \\
\text { relationship of ...? Of po...? }\end{array}$ \\
\hline 34 & Pierre & possessif & possessive \\
\hline 35 & $\mathrm{P} 2$ & $\begin{array}{l}\text { Voilà! A qui appartient le } \\
\text { nom? C'est le tien, c'est le } \\
\text { mien, c'est le sien, c'est son } \\
\text { nom, votre nom, donc c'est } \\
\text { donc un rapport de } \\
\text { possession... Comment on les } \\
\text { appelle comment ces mots? } \\
\text { Vous aviez trouvé la bonne } \\
\text { solution tout à l'heure, c'était } \\
\text { bien, vous avez dit des...? }\end{array}$ & $\begin{array}{l}\text { Well done! And to whom does the } \\
\text { name belong? It's mine, it's } \\
\text { yours, it's his/her name, your* } \\
\text { name, so ... so it's a relationship } \\
\text { of possession ... What are they } \\
\text { called, those words? You found a } \\
\text { good solution earlier, it was good, } \\
\text { you said they were ...? } \\
\text { [*polite form] }\end{array}$ \\
\hline 36 & Pierre & Des pronoms relatifs! & Relative pronouns! \\
\hline
\end{tabular}

Excerpt 2 Partial transcript of Dutch, session 2 (NLS2), group B5

The exchange in Excerpt 2 is more of a dialogue between teacher and student than among students: P2, a female teacher, tries to guide one of them in his reflection, but the way she proceeds does not really encourage the construction of metalinguistic thought. The students are trying to find answers to please her, but end up randomly giving any kind of unsuitable answer, in an unreflective way.

This teacher's "leadership" style (Lewin et al. 1939) seems to be autocratic. As Zoltan Dörnyei and Angi Malderez put it,

An authoritarian role, together with highly structured tasks, however, does appear to many teachers as safer and more efficient than leaving the students, to a certain extent, to their own devices - and indeed the Lewin et al. (1939) study did point to the greater productivity of autocratic groups (Dörnyei and Malderez 1999, p. 166).

Nonetheless, for maximum engagement to take place, it is important that the group vertex, as presented in the adapted version (Figure 1) of Faerber's tetrahedron, functions as an entity in which the students collaborate to solve the problem by themselves, whereas the teacher is merely facilitating the reflection. 
It would therefore be interesting to compare the pre- and post-tests to find out whether P2's "autocratic" attitude reflected in Excerpt 2 had modified the effects of PAUL sessions on learning outcomes.

In what way does engagement in PAUL sessions impact learning outcomes?

Learning outcomes in metasemantic PAUL sessions (session 1) can be studied through the use of learning strategies. According to previous research on the strategic use of learning strategies during metasemantic PAUL sessions (Dahm 2015), it appears that

the students mainly resort to comparison and translation strategies, while strategies of inferencing and deduction seem to be more difficult to implement. Comparison is the most frequently used strategy by the greatest number of groups, but the source language depends on a great number of factors (ibid., p. 59).

When comparing the pre- and post-tests, the most marked difference I observed between the results of the participant group and the control group concerned the inferencing strategy. The control group resorted to inferencing by $12 \%$, whereas the participant group used this strategy in $18 \%$ of the cases to enhance their understanding of the post-test. However, these results merit further examination. The analysis of the evolution of the results between the pre- and post-test for the participant group showed an important teacher effect. It is remarkable indeed that the increase was 34\% for the class of the first teacher, P1 (and about 26\% for P4 and P5), while for P2 it was only 4\% (and for P3 11\%). I have already pointed out the differences in the teachers' attitudes: I described P1 as a "facilitator", while P2 functioned more according to an "autocratic" model. It therefore seems that spontaneous adoption of the inferencing strategies is fostered by group work in which the teacher has a limited role, a condition which leads to true co-inferring.

The effect of group work which leads to maximum engagement is also apparent during the metasyntactic PAUL sessions (session 2). Again, based upon Chi and Wylie's definition, a maximum level of engagement does seem to enable learners to co-create new sentences. To do so, they need to take risks and overcome their wariness of anything new. Here is an example of the risk-taking in the metasyntactic session on Finnish (last language introduced) where students created new sentences, building upon the original ones. The original text was the following:

Päivi: " Rakastatko musiikkia?” [Do you like music?]

Timo: "Kyllä, minä rakastan. Lataan paljon musiikkia Internetistä.” [Yes, I do. I download a lot 
of music from the Internet]

Päivi: "Soitatko musiikkia?" [Do you play music?]

Timo: "Kyllä, minä soitan. Soitan pianoa. Sisareni Eija ei soita pianoa, mutta hän soittaa

kitaraa. [Yes, I do. I play the piano. My sister Eija doesn't play the piano, but she plays the guitar]

Entä sisaresi Nina?" [And your sister Nina?]

Päivi: "Sisareni Nina rakastaa rap-musiikkia. Rakastaako sisaresi Eija myös rap-musiikkia?"

[My sister Nina likes rap-music. Does your sister Eija like rap-music too?]

Timo: "Ei, hän ei rakasta." [No, she doesn’t.]

To describe the way students created their sentences, I used the following code:

- $\quad 0$ designates the replacement of one element with another, without any real risk-taking. An example from the Finnish sessions (FinnS2 B7) is: "Rakastatko Internetistä? Soitan Kitaraa?"[Do you love the Internet? I play the guitar?]. The original sentences were: "Rakastatko musiikkia?" "Soitan pianoa". Only the substantive was changed from the original sentence, without any other modification. It is a minimal creation where the group remains in its comfort zone.

- $\quad+$ designates a change of at least two elements, entailing a more complete manipulation of the sentence. An example from another Finnish session (FinnS2 A1) is: "Lataan kitaraa musiikkia ja pianoa musiikkia. Soitan rap mutta ei soitan kitaraa. Sisareni rakastataa pianoa" [I download guitar music and piano music. I play rap, but I do not play the guitar. My sister love the piano]. The original sentences they built upon were: "Lataan paljon musiikkia Internetistä", "Soitan pianoa. Sisareni Eija ei soita pianoa, mutta hän soittaa kitaraa" [I download music from the Internet. I play the piano. My sister Eija doesn't play the piano, but she plays the guitar] Even if there are some mistakes, a real act of creativity took place: the group tried to set up new sentences building upon their previous observations, and took thoughtful risks.

- Abs means that no sentence was created.

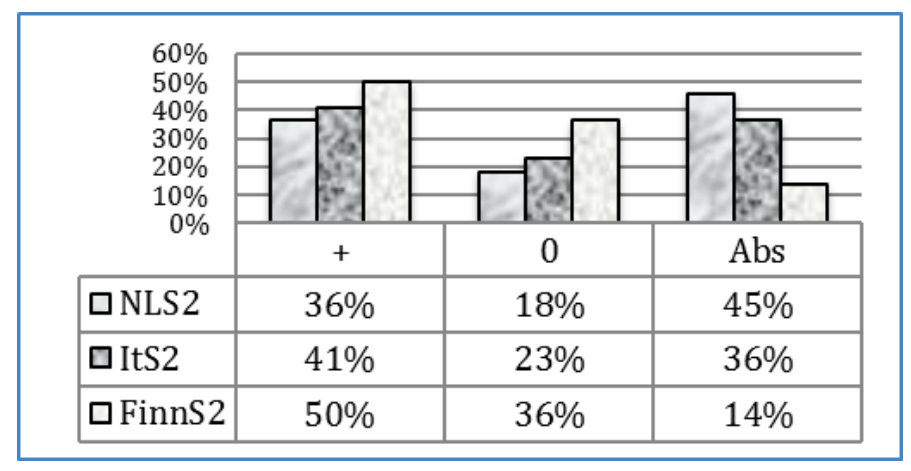

Note $\quad \mathrm{NL}=$ Dutch; $\mathrm{S} 2=$ session $2 ; \mathrm{It}=$ Italian Finn = Finnish

Figure 2 Risk-taking during metasyntactic PAUL sessions 
The results of the analysis speak for themselves (Figure 2): during the Dutch session (NLS2), $45 \%$ of the students had not created or not dared to create sentences (column Abs). For the Finnish session (FinnS2), the corresponding Abs result is only 14\%. For risk taking (columns 0 and + respectively), Dutch is lowest at $18 \% / 36 \%$, and Finnish highest at $36 \% / 50 \%$. It therefore seems likely that the repetition of activities allowed students to change their attitude towards unknown languages. They "took possession" of the language (one cannot speak of ownership here) which they handled more easily. Similarly, the groups hesitated less and less to mobilise their knowledge or know-how, which also reflects a positive development in attitudes. Since these are three different languages, this shift cannot be attributed to increased language proficiency. It rather underlines the establishment of a strategic advantage (as defined by Herdina and Jessner 2002), usually specific to multilingual speakers. The distributed knowledge shared among the group led to a maximum level of engagement which enabled them to overcome their wariness of anything new and also enabled them to truly coconstruct new knowledge.

Through these PAUL sessions on languages the students were not studying as a subject, the participants built abstract and unconscious schemata enabling them to solve the problem and thus developed cognitive strategies. Most of these strategies were successfully transferred from one session to another, as students managed to establish connections between different linguistic situations (for more detailed results, see Dahm 2015).

Finally, some students consciously used the learning strategies they had developed during the PAUL sessions both inside and outside the school context. Indeed, the evaluation of the post-study survey underlines the fact that $35.8 \%$ of the students reflected upon other unknown languages by themselves, thus transferring to personal situations the strategies developed during PAUL sessions. Even though the questionnaire responses represent merely declarative "data", the effects of PAUL sessions do seem to exceed expectations since they appear to have changed the cognitive functioning of some students who are now on the lookout for any kind of multilingual situation.

Can learner engagement foster a positive attitude towards "foreignness" and eventually facilitate social inclusion?

A maximum level of engagement can also be achieved when students and teachers work together, co-elaborating new knowledge. However, it seems quite challenging to have a true interaction resulting in the creation of new knowledge none of the partners knew before, when 
one of them is the teacher and thus supposedly an expert. And yet, two teachers involved in our action research took PAUL sessions to the next level; they decided to explore the way PAUL sessions might contribute to including multilingual learners (MLL) from a migrant background.

Beyond the scope of the large-scale study, teacher P3 decided to try sessions with her three Turkish students and teacher P8 with her two Portuguese students. Once again, none of the teachers knew the languages which the sessions were going to be about. Both teachers met their multilingual students during a free period, and asked them to co-create a text similar to one of the texts that had been worked on during the PAUL sessions. They report having had exciting conversations with their students who had to meet the following requirements, related to the strategies to be implemented to understand the text: the text had to contain cognates $^{12}$ (some could be repeated) enabling a certain number of comparison strategies, either with French (L1) or with English (L2). Clues allowing the use of inferencing strategies, bottom-up (e.g. capital letters or numbers) and top-down (general knowledge) deduction strategies were also required (see Table 2).

Table 2 Required strategies and indicators to create a text

\begin{tabular}{|l|l|l|l|l|}
\hline \multirow{2}{*}{ Strategies } & \multirow{2}{*}{ Comparison } & \multicolumn{1}{|c|}{ Inferencing } & \multicolumn{1}{c|}{ Deduction } \\
\cline { 4 - 5 } & & & \multicolumn{1}{c|}{ Bottom-up } & \multicolumn{1}{c|}{ Top-down } \\
\hline \multirow{5}{*}{ Indicators } & $\begin{array}{l}\text { comparison with } \\
\text { L1 (French) } \\
\text { and/or L2 } \\
\text { (English) }\end{array}$ & $\begin{array}{l}\text { relying on several } \\
\text { elements of the } \\
\text { sentence to } \\
\text { understand } \\
\text { meaning }\end{array}$ & $\begin{array}{l}\text { relying on capital } \\
\text { letters or numbers } \\
\text { (= input) }\end{array}$ & $\begin{array}{l}\text { relying on } \\
\text { general } \\
\text { knowledge } \\
\text { (= external input) }\end{array}$ \\
\hline
\end{tabular}

The three Turkish students collaborated in creating one Turkish text, and the two Portuguese students created one Portuguese text together, without the presence of the teacher. They then asked their parents for help to ensure the final version of the text was correct.

When the two texts were ready, each teacher presented their MLLs' text to their class in the exact same way as during the previous metasemantic sessions: no announcement of the language, individual work for five minutes, then group work for twenty-five minutes followed by a class synthesis guided by the teacher. Finally, when the nature of the language was revealed, the authors of the text came forward and then read the text so that the other students could hear the language too.

\footnotetext{
12 "Cognate languages and words have the same origin, or are related and in some way similar" (McIntosh,
} 2013). 
The teachers report having observed a great deal of involvement and pride on the part of the MLLs and a very positive attitude on the part of the remaining students who genuinely took an interest in their classmates' language and pronunciation and wanted to know more about some cultural specificities. The teachers also underline the amount of work this operation required from their MLLs, some of whom had not been schooled in their mother tongue and therefore needed external advice. Despite this, they had volunteered to create such a session. Teacher P3 finally indicates having met the father of one of her MLL students, who was very happy to have been able to talk about the Turkish language with his son and to contribute to the session.

Not all MLL students however managed to create a text. Another student, an MLL speaking Arabic, had initially stated her interest in creating such a session, transcribing Arabic into the Latin alphabet. However, being on her own (no one else had volunteered) and the teacher not being able to help her, she finally abandoned the project.

\section{Conclusion}

As has been explored in this article, there is reason to believe that PAUL sessions enable students to increase their engagement in their learning, leading to maximum benefits, be it for the development of learning strategies or for their opening up to unknown languages.

Indeed, since none of the students knew the language they were confronted with (a main feature of PAUL sessions), they truly needed to collaborate in co-creating new knowledge. This can only take place if the teacher plays the part of the facilitator and lets go of an autocratic (yet reassuring) attitude. But once the group functions efficiently, students actively engage in their learning and overcome their initial fears related to the unknown. They thus develop more challenging learning strategies (inferencing, for instance) which they are able to transfer to the learning of English (L2) or even to other linguistic situations (see Dahm 2015). During metasyntactic PAUL sessions, they overcome their initial fears and together take more and more risks to create new sentences, in an efficient way. This is most probably one of the first attitudes which needs to be encouraged if we want students to set up a more tolerant society.

Even though the research design led me to observe multilingual and quasi monolingual students separately, it is likely to be beneficial for both monolingual and multilingual learners to be in mixed groups when discovering an unknown language. Students would most probably be able to benefit from the shared knowledge and might be able to increase further 
understanding. Asking MLLs to explain how they managed to understand the texts and/or create new sentences would most probably lead to a higher level of metalinguistic knowledge, which in turn might be beneficial to their mastery of the local L1 (in this case, French).

Even though the data we gathered in this study only enable us to underline the effects of PAUL sessions on learner engagement and the enhanced positive attitudes towards foreignness, it seems that setting up further PAUL sessions with students from a migrant background might be a means to bridge the gap between communities. PAUL-experienced students become used to discovering new languages and shed their initial pre-conceived ideas; once they playfully discover the language of their peers, they want to know more about the other's culture.

Collaborating in order to solve the problems which confronted the group is the first step towards social cohesion. Furthermore, asking MLL students to contribute to the unfolding of such sessions can induce them to apply cognitive strategies, develop their knowledge of their own language and extend their pride by passing it on to their fellow classmates. It seems likely that involving students from a migrant background in setting up such sessions could enhance not only their linguistic abilities but also their feeling of inclusion and, finally, increase social cohesion among learners. However, further research is needed to scientifically explore this aspect.

Acknowledgements This article draws on research done in the INCLUDE (EC Erasmus+) project, which is part of the European Commission's lifelong learning programme.

\section{References}

Bialystok, E. (1987). Words as things: Development of word concept by bilingual children. Studies in Second Language Acquisition, 9, 133-140.

Bono, M. (2008). «Quand je parle en langue étrangère, je parle anglais ». Conscience métalinguistique et influences interlinguistiques chez les apprenants plurilingues ["When I speak in a foreign language, I speak English." Metalinguistic awareness and interlingual influences in multilingual learners]. In M. Candelier (Ed.), Conscience $d u$ plurilinguisme. Pratiques, représentations et interventions [Awareness of plurilingualism. Practices, representations and interventions] (pp. 93-107). Rennes: Presses Universitaires de Rennes.

Busch, B. (2011). Trends and innovative practices in multilingual education in Europe: An overview. International Review of Education, 57(5-6), 541-549. http://doi.org/10.1007/s11159-011-9257-1

Candelier, M. (2008). Approches plurielles, didactiques du plurilinguisme : le même et l'autre [Pluralistic approaches, didactics of plurilingualism: The same and the other]. Les Cahiers de l'Acedle, 5(1), 65-90. 
Cathomas, R., \& Carigiet, W. (2006). Auf dem Weg zu einer intergralen (Mehr)Sprachendidaktik [On the way to integral (multi)language didactics]. In W. Wiater \& G. Videsott (Eds), Schule in mehrsprachigen Regionen Europas [School Systems in Multilingual Regions of Europe] (pp. 137-152). Frankfurt/Main: Peter Lang.

Cenoz, J., Hufeisen, B., \& Jessner, U. (2001). Cross-linguistic influence in third language acquisition. Clevedon: Multilingual Matters.

Chi, M. T. H., \& Wylie, R. (2014). The ICAP Framework: Linking cognitive engagement to active learning outcomes. Educational Psychologist, 49(4), 219-243. Retrieved 15 March 2017 from http://chilab.asu.edu/papers/ChiWylie2014ICAP.pdf.

Clyne, M. (2003). Dynamics of language contact. Cambridge: Cambridge University Press.

$\mathrm{CoE}$ (Council of Europe) (2001). Common European framework of reference for languages. Cambridge: Cambridge University Press.

Cummins, J. (1991). Interdependence of first- and second-language proficiency in bilingual children. In E. Bialystok (Ed.), Language processing in bilingual children (pp. 70-89). Cambridge: Cambridge University Press.

Dahm, R. (2013). Effets de l'introduction d'une approche plurielle fondée sur des langues inconnues sur le système didactique. Des éléments de cadrage à la mise en place expérimentale en classe d'anglais au collège [Effects of introducing a pluralistic approach based on unknown languages on the didactic system: From framing elements to the experimental set-up in English classes in lower seciondary school]. Thèse de doctorat [doctoral thesis] sous la direction de M.-C. Deyrich, soutenue le 7 novembre 2013 à l'université de Bordeaux-Segalen, Bordeaux.

Dahm, R. (2014). Les «Approches Plurielles fondées sur des Langues Inconnues » ou comment valoriser la dimension affective de l'enseignement des langues ["Pluralistic Approaches based on Unknown Languages" or how to value the affective dimension of language teaching]. Etudes en Didactique des Langues, 23-24, 79-102.

Dahm, R. (2015). Developing cognitive strategies through pluralistic approaches. In G. De Angelis, U. Jessner \& M. Kresic (Eds), Crosslinguistic influence and crosslinguistic interaction in multilingual language learning (pp. 43-70). London: Bloomsbury.

Dewey, J. (1966 [1916]). Democracy and education. An introduction to the philosophy of education. New York: Free Press.

Deyrich, M.-C. (2001). Quelles médiations pour une gestion efficace de la transposition didactique en anglais de spécialité ? [Which kinds of mediation are best for effective didactic transposition in teaching English as a specialty subject?] $A S p, 31-33,143-152$.

Dörnyei, Z., \& Malderez, A. (1999). The role of group dynamics in foreign language learning and teaching. In J. Arnold (Ed.), Affect in language learning (pp. 155-169). Cambridge: Cambridge University Press.

Edwards, R., Armstrong, P., \& Miller, N. (2001). Include me out: Critical readings of social exclusion, social inclusion and lifelong learning. International Journal of Lifelong Education, 20(5), 417-428.

Ellis, R. (2003). Task-based language learning and teaching. Oxford: Oxford University Press.

Extra G., \& Yagmur K. (Eds) (2012). Language rich Europe: Trends in policies and practices for multilingualism in Europe. Cambridge: Cambridge University Press, on behalf of the British Council. Retrieved 14 March 2017 from http://www.teachingenglish.org.uk/sites/teacheng/files/LRE English version final 01. pdf.

Faerber, R. (2002). Le groupe d'apprentissage en formation à distance : ses caractéristiques dans un environnement virtuel [The distance learning learning group: Its characteristics in a virtual environment]. In F. Larose \& T. Karsenti (Eds), La place des TICE en formation initiale et continue à l'enseignement : bilan et perspectives [The role of 
ICTs in initial and continuing education: Assessment and perspectives] (pp. 99-128). Sherbrooke, QC: Editions du CRP, Université de Sherbrooke.

Gajo, L. (2001). Immersion, bilinguisme et interaction en classe [Immersion, bilingualism and classroom interaction]. Paris: Didier.

Herdina, P., \& Jessner, U. (2002). A dynamic model of multilingualism. Perspectives of change in psycholinguistics. Clevedon: Multilingual Matters.

Houssaye, J. (1988). Le triangle pédagogique [The educational triangle]. Bern: Peter Lang.

Hulstijn, J., \& Hulstijn, W. (1984). Grammatical errors as a function of processing constraints and explicit knowledge. Language Learning, 34(1), 23-43.

INCLUDE (2014). INCLUDE: Language policy for active social inclusion [flyer]. Brussels/Luxembourg: INCLUDE Network. Retrieved 9 March 2017 from http://www.includenetwork.eu/images/Leaflet2/Leaflet2 EN.pdf.

Lewin, K., Lippitt, R., \& White, R. (1939). Patterns of aggressive behavior in experimentally created "social climates". Journal of Social Psychology, 10, 271-299.

Lindblad, S. (2005). Knowledge, governance and social inlcusion/exclusion. A report from a European Union research project. Gothenburg: Göteborgs universitet, Institutionen för pedagogik och didaktik.

McIntosh, C. (Ed) (2013). Cambridge advanced learner's dictionary (4th edn). Cambridge, UK: Cambridge University Press.

Nordin, A. (2008). Educating inclusion? Aspects of exclusion within the inclusive policy concept of Lifelong Learning. Paper presented on 10 September at the European Conference on Educational Research (ECER) in Gothenburg.

Orlando, N., \& Cullen, J. (2016). Roadmap for integration of language learning in inclusion policies in Europe. Deliverable 9. Bordeaux etc.: INCLUDE (Language policy for active social inclusion) network. Retrieved 15 February 2017 from http://www.includenetwork.eu/DOCUMENTS/D9\%20-\%20ROADMAP.pdf.

Pea, R. D. (1998). Distributed intelligence and the growth of virtual learning communities over the global Internet. PC97 Keynote address presented at the Council for Improving Educational Computing, Kyoto, Japan.

Reeve, J. (2012). A self-determination theory perspective on student engagement. In S. L. Christenson, A. L. Reschly, \& C. Wylie (Éds), Handbook of research on student engagement (pp. 149-172). Boston, MA: Springer.

Ringbom, H. (2007). Cross-linguistic similarity in foreign language learning. Clevedon: Multilingual Matters.

Swain, M. (2000). The output hypothesis and beyond: Mediating acquisition through collaborative dialogue. In J. Lantolf (Ed.), Sociocultural theory and second language acquisition (pp. 97-114). Oxford: Oxford University Press.

Van Driel, B., Darmody, M., \& Kerzil, J. (2016). Education policies and practices to foster tolerance, respect for diversity and civic responsibility in children and young people in the EU (NESET II Report). Luxembourg: Publications Office of the European Union. $\begin{array}{lllll}\text { Retrieved } & 15 & \text { February } & 2017 & \text { from }\end{array}$ http://ec.europa.eu/dgs/education_culture/repository/education/library/study/2016/neseteducation-tolerance-2016_en.pdf.

Wellborn, J. G. (1991). Engaged and disaffected action: The conceptualization and measurement of motivation in the academic domain. Unpublished doctoral dissertation, University of Rochester, New York.

\section{The author}


Rebecca Dahm is a lecturer in language didactics at the University of Toulouse (France) and belongs to the laboratory CLLE-ERSS (CNRS-UMR 5263) researching linguistics, language didactics and psycholinguistics. She is also a teacher trainer at the Teacher training institution (ESPE) of the University of Toulouse-Jean Jaurès. She has been working on the benefits for monolingual learners and teachers of being confronted with artificial multilingual situations and is currently exploring ways to enhance social inclusion of multilingual learners from a migrant background.

Appendix1: Text in Dutch

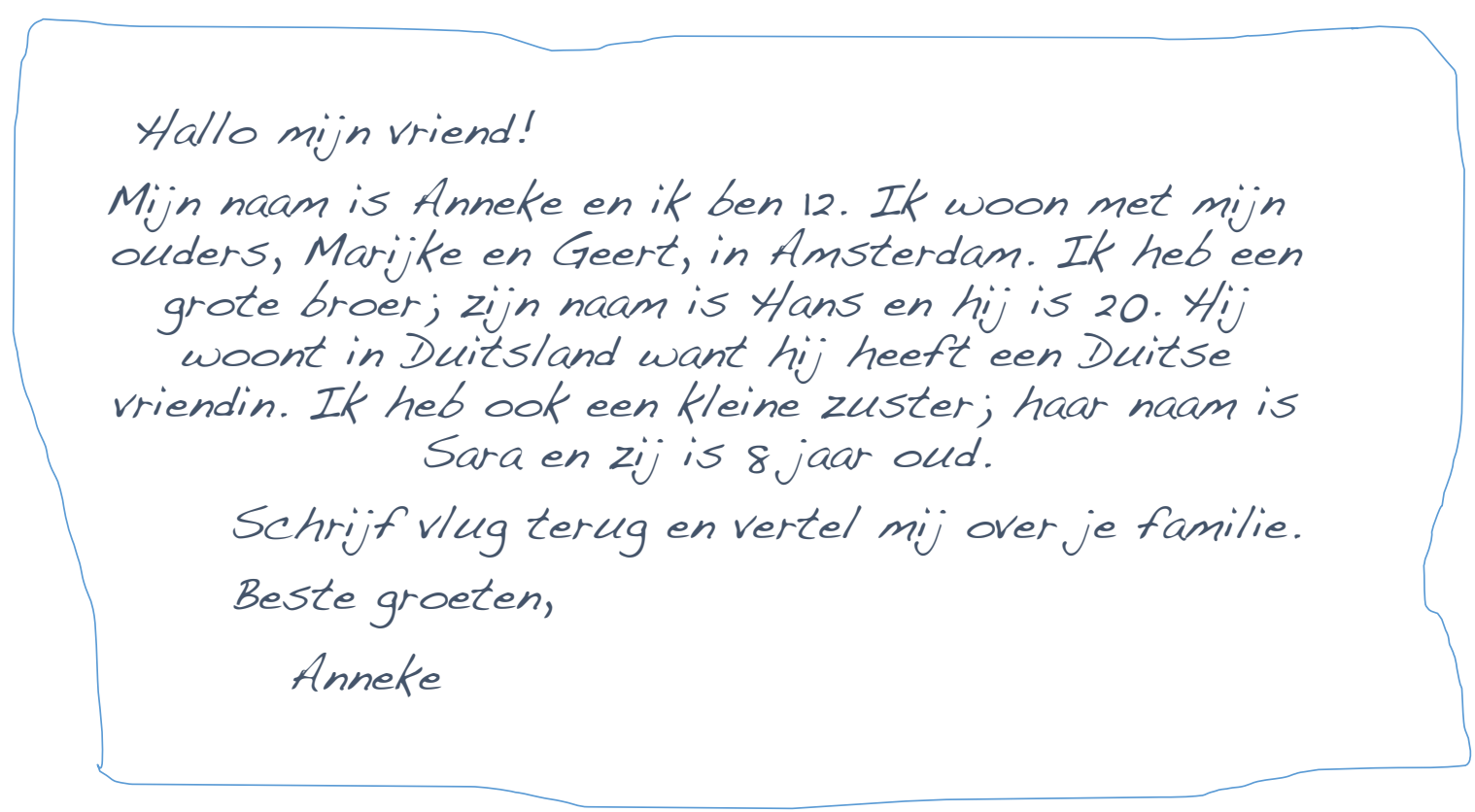

Translation of Appendix 1

Hello my friend,

My name is Anneke and I'm 12. I live with my parents, Marijke and Geert, in Amsterdam. I have a big brother; his name is Hans and he is 20. He lives in Germany because he has a German girlfriend. I have also a younger sister; her name is Sara and she is 8 .

Write back to me soon and tell me about your family.

Kind regards,

Anneke 